7 (2016)

D0I: $10.18276 /$ rk.2016.7-10

Iwona Puchalska

Uniwersytet Jagielloński

\title{
Maszyny muzyczne, maszyny poetyczne: urządzenia i nośniki fonograficzne w wierszach poetów polskich $\mathrm{XX}$ wieku ${ }^{1}$
}

\author{
Ponieważ istota techniki nie jest niczym technicznym, \\ zatem istotowy namysł nad techniką i rozstrzygający spór z nią \\ muszą się dokonywać w obszarze, który z jednej strony \\ jest spokrewniony z istotą techniki, z drugiej zaś jest od niej z gruntu różny. \\ Takim obszarem jest sztuka [...].
} (Heiddeger, 2002: 46)

1.

Praktycznie o wszystkich twórcach wieku XX zainteresowanych muzyką można powiedzieć, że są oni wychowani w kulturze fonograficznej - a jednak niemal dla każdego z nich posiada ona inne oblicze, uzależnione nie tylko od jego osobistego stosunku do sztuki dźwięków, ale i od etapu rozwoju fonografii, która w ostatnim stuleciu ewoluowała nieustannie, upowszechniając się i proponując coraz to nowe nośniki, a co za tym idzie - tworząc coraz to nowe ramy dla sytuacji muzycznych. Poczynając od słynnego „gramopatefonu” z wiersza Młodożeńca (XX wiek), fonograf, patefon, gramofon, adapter, magnetofon, walkman, discman czy odtwarzacz kompaktowy pojawiają się coraz częściej w utworach lirycznych, podobnie jak przypisane im nośniki dźwięków - płyta, szpula, kaseta. Zazwyczaj ich funkcja

\footnotetext{
Artykuł powstał w ramach badań stanowiących realizację projektu sfinansowanego ze środków Narodowego Centrum Nauki przyznanych na podstawie decyzji numer DEC-2013/11/B/ HS2/02881.
} 
jest stosunkowo skromna - są wskazane lub implikowane jako źródło muzyki, rozbrzmiewającej w rozmaitych przestrzeniach i okolicznościach. Niekiedy jednak z bohaterów drugoplanowych stają się pierwszoplanowymi; ich właściwości, kształt, sposób działania stają się przedmiotem obserwacji, namysłu, punktem wyjścia dla metafor i źródłem symbolicznych sensów.

Co znamienne, alegoryzacja kształtu i sposobu działania nośników dźwięku i urządzeń do ich odtwarzania nie stanowi domeny wyłącznie poetów, czy szerzejliteratów. Jako jeden z pierwszych posłużył się nią Theodor W. Adorno, i to w tekście zdecydowanie fonografii nieprzychylnym. W eseju zatytułowanym Forma ptyty (Die From der Schallplatte) stwierdzat:

Nie bez powodu wyrażenie „płyta”, bez dodatkowych określeń, jest w jednakowym znaczeniu używana w fotografii i fonografii. Oznacza ono dwuwymiarowy model rzeczywistości, który pozwala się dowolnie zwielokrotniać, odrywać od czasu i przestrzeni, i wprowadzać na rynek. W tym celu musiała ona poświęcić swój trzeci wymiar: swoją wysokość i głębię".

(Adorno, 1998: 530-531)²

Płaskość płyty, jak również jej uniwersalność jako nośnika nie tylko dźwięku, ale i obrazu jest dla filozofa widomym znakiem utraty wielowymiarowości właściwej dziełu sztuki istniejącemu w rzeczywistości, co sprawia, że z obiektu (Objekt) staje się ono rzeczą (Ding); ponadto płyta, jego zdaniem, „cynicznie” demonstruje wyższość rzeczy nad człowiekiem (Adorno, 1998: 530-531)33, jest narzędziem dehumanizacji. Adorno dokonuje konfrontacji przedmiotu, jakim jest nośnik dźwięku, z jednostkami ludzkimi, których obecność do tej pory warunkowała istnienie muzyki; traktuje przy tym nagranie jako rzecz wypierającą wykonawców, śpiewaków, instrumentalistów, a nie reprezentującą ich sztukę; jako zjawisko pojawiające się zamiast nich, a nie w ich imieniu. Dodać należy od razu, że ta pełna niechęci, miejscami nawet nienawistna kontemplacja przedmiotu, który niejako

2 „Nicht umsonst wird der Ausdruck «Platte», ohne Zusatz, in Photographie und Phonographie gleichsinnig gebraucht. Er bezeichnet das zweidimensionale Modell einer Wirklichkeit, die sich beliebig multiplizieren, nach Raum und Zeit versetzen und auf dem Markte tauschen läßt. Dafür hat sie das Opfer ihrer dritten Dimension zu bringen: ihrer Höhe und ihres Abgrunds" [tłum. I.P.].

3 „Sie [die Schallplatte] entstammt, vielleicht als erste der kunst-technischen Erfindungen, bereits jenem Zeitalter, das die Übermacht der Dinge über den Menschen zynisch bekennt, indem es die Technik von humanen Anforderungen und humanem Bedarf emanzipiert und Errungenschaften bereithält, ohne daß ihnen primär ein menschlicher Sinn zukäme; statt dessen wird der Bedarf erst durch die Reklame produziert, wenn das Ding vorliegt und nach eigener Bahn kreist" [tłum. I.P.]. 
wciela muzykę istniejącą w nagraniu, który uwidacznia, materializuje jej złowróżbne działanie, z czasem nieco złagodniała, bowiem poglądy Adorna na temat fonografii ewoluowały, a jego przekonanie na temat jej szkodliwości nie było stabilne.

W obserwacjach Adorna na temat płyty gramofonowej jednak metafora i konceptualizacja stanowią jedynie rodzaj efektownego kostiumu, w jaki odziana została refleksja w istocie swojej muzykologiczna; pełnią rolę przede wszystkim perswazyjną. Inaczej rzecz się ma w tekstach poetyckich, w których wspominane są nośniki i urządzenia fonograficzne. Brak owego „trzeciego wymiaru”, o którym pisał Adorno, brak „obecności” związany z fonografią nie jest dla poetów brakiem bolesnym - jest raczej możliwością, inspiracją; widzą w nim nie ograniczenie, lecz otwarte miejsce, miejsce dla wyobraźni. Przyjrzyjmy się kilku przykładom.

\section{2.}

Cykl Ptyty Carusa Marii Pawlikowskiej-Jasnorzewskiej pochodzi z tomu Profil biatej damy (1930), który to tom - jak zresztą świadczy już sam tytuł - jest szczególnie, by tak rzec, „uduchowiony”. Jak wiadomo, poetka żywiła do idei spirytystycznych duże upodobanie, oscylujące między bliską wiary fascynacją a ironicznym, humorystycznym dystansem i wpisujące się w nawrót mody na spirytyzm, jaki dał się zauważyć w Europie po I wojnie światowej (Kwiatkowski, 1969: LII-LIII). Co jednak charakterystyczne, tematyka spirytystyczna jest stosunkowo rzadko - jak na spore nasycenie poezji Pawlikowskiej tego typu wątkami - tematem głównym wierszy. Zazwyczaj jest ona podstawą poetyckiego konceptu, odsyłającego do innych sfer ludzkiego doświadczenia ${ }^{4}$. Podobnie zresztą rzecz się ma z tematami muzycznymi, zaznaczającymi swą obecność w tomie Dancing (1927) - poetyckie reprezentacje sztuki dźwięków są dla poetki punktem wyjścia dla refleksji ogólniejszej, zwłaszcza egzystencjalnej.

W każdej z miniatur składających się na Ptyty Carusa ${ }^{5}$ konceptualizacja odsłuchu nagrań prowadzi ku innej poincie, wyraża inną myśl, wiąże się z inną refleksją; można więc, jak sądzę, potraktować je jak cykl poetyckich wariacji na temat muzyki fonograficznej, a zwłaszcza na temat związanej z nią niepokojącej, tajemniczej obecności czegoś fizycznie nieistniejącego.

\footnotetext{
4 Szerzej na temat tego aspektu cyklu Płyty Carusa piszę w artykule: Dźwiękowe medium, czyli o watkach spirytystycznych w poetyckiej ,muzykologii”, „Ruch Literacki” (w druku).

5 Konsekwencje zastosowania formuły cyklu analizuje M. Szargot (2005: 345-352).
} 
Cykl otwiera kontemplacja narzędzia odsłuchu:

Kołuje żałobny dysk

w trumiennem pudle odkrytem.

Caruso śpiewem wytryska, a śmierć wtóruje mu zgrzytem...

Caruso - żywy aksamit,

życie ze szczęściem zżyte,

najżywszy ton między nami!

A śmierć zatrzymuje płytę...

(Pawlikowska-Jasnorzewska, 1969: 129-130).

Wiersz, dla którego punktem wyjścia jest odtwarzanie płyty, wprowadza wyobrażenie śmierci - śmierci obecnej nieustannie i w każdej chwili towarzyszącej życiu - nieodłącznego cienia życia, szpecącego je zgrzytu. Poetka poddaje metaforyzacji sporo cech realizacji fonograficznej: kształt gramofonu, skojarzony z trumną6, czarny, „żałobny” kolor płyty czy niedoskonałości odtwarzania („śmierć wtóruje mu zgrzytem”). O samej muzyce nie wiemy nic poza tym, że jest muzyką wokalną. Śpiew Carusa jest metonimią muzyki, a zarazem, jako głos już nieżyjącego człowieka (śpiewak zmarł w 1927 roku), jest metonimią „życia po śmierci”. W istocie przypadek tego tenora, który szczególnie chętnie i często utrwalał swój śpiew w nagraniu, i który w dużej mierze przyczynił się do nobilitacji tej formy obcowania z muzyką, był jedną z pierwszych realizacji owej nowej postaci artystycznej nieśmiertelności, jaką zapewniała fonografia, przenosząc efemeryczną do tej pory śpiewaczą sławę poza próg śmierci. Możliwość słuchania artysty, który już umarł, była pod koniec lat 20. XX wieku doświadczeniem nadal nowym i niewątpliwie stymulującym wyobraźnię - niesamowitość tego wrażenia trudno nam dziś zapewne w pełni docenić. Wydaje się jednak, że funeralny koncept wiersza zrodził się nie z samej obserwacji urządzenia grającego, lecz ze świadomości, że odtwarza ono „śpiew umarłego”; podobieństwo gramofonu do trumny jest więc wrażeniem wtórym, niejako pochodną jego niesamowitych właściwości.

6 Poetka nie podaje nazwy odtwarzacza, który opisuje, jednak porównanie do trumny sugeruje, że był to mechanizm skrzynkowy, bez tuby, z głośnikami wmontowanymi w obudowę, wykonany zazwyczaj z drewna, niekiedy - w wersji przenośnej - ze skóry i zamykanym wiekiem; modele tego typu, produkowane zarówno przez firmy europejskie, jak i amerykańskie od 1910 roku, były rozpowszechnione w latach 20. i 30; nazywano je gramofonami, zwłaszcza jeśli były produkcji angielskiej lub amerykańskiej, lub patefonami, jeśli były produkcji francuskiej (Marty, 1979: 100; Lesueur, 2004: 53). 
Quasi-muzykologiczna refleksja ontologiczna łączy się w tej miniaturze harmonijnie z (bliskim topice ekspresjonistycznej) obrazem „życia w śmierci”, czy nawet pogrzebania za życia. Ów „żałobny dysk” w otwartym - c i ą g le je s z c z e otwartym - trumiennym pudle to wyrazista metafora bardzo charakterystycznego dla utworów Pawlikowskiej z tego okresu, a bliskiego wątkom leśmianowskim, stanu zawieszenia pomiędzy życiem a śmiercią (Kwiatkowski, 1969: LV). Gramofon jest tu urządzeniem spirytystycznym par excellence: brzmienie głosu i ruch, obroty płyty - to życie; dziwne, niepełne, pośmiertne, ale jednak życie, natomiast milczenie i bezruch zatrzymanego krążka - to śmierć ostateczna, „śmierć wtóra”. Działanie gramofonu staje się również impulsem do refleksji wanitatywnej. Pośrednicząca rola muzyki, której nie słucha się „na żywo”, lecz z „martwego” nośnika - to idealna ilustracja spirytystycznego wyobrażenia o zmarłych obcowaniu, lecz także sytuacji egzystencjalnej każdego człowieka, świadomego swej śmiertelności.

\section{3.}

Czujnie rejestrujący struktury dźwiękowe wszędzie, gdzie się pojawiały, w każdej sferze rzeczywistości (Wiśniewski, 2004: 4), Białoszewski nie szukał jednak zasadniczo kontaktu z muzyką na żywo; na koncerty wybierał się relatywnie rzadko. Słuchał jej natomiast bardzo intensywnie z płyt $^{7}$ - był słuchaczem zasadniczo fonograficznym. Jednak mimo tak bliskiego obcowania z muzyką gramofonową - a może właśnie z tego powodu - samemu urządzeniu do odtwarzania dźwięku nie poświęcał zbyt dużo uwagi; w jego wierszach i prozie źródło muzyki jest zazwyczaj implikowane. Są jednak utwory, w których odgrywa ono szczególną rolę.

Tak dzieje się w Karuzeli z madonnami, otwierającej cykl Ballady peryferyjne. Tekst ten odznacza się wyjątkową dźwięcznością, o czym decyduje nie tylko układ rymów, lecz także sylabotoniczna organizacja znacznych przestrzeni tekstu. Pod względem tematu i obrazowania, utwór kontynuuje zasadniczo strategie poetyckie poprzedzających go, wczesnych cyklów poety, operujących z jednej strony licznymi odwołaniami do sztuk plastycznych, z drugiej - estetyką prowincji i dawności, poetyką czasu zatrzymanego. W Karuzeli z Madonnami jednak eksplorowaną wcześniej przestrzeń wiejsko-prowincjonalną zastępuje kultura przedmieść - zbliżamy się do dużego miasta, które wkrótce wypełni wiersze Białoszewskiego.

7 „Od końca lat sześćdziesiątych, kiedy Miron sprawił sobie dobry, czeski adapter (...) słuchał
muzyki niemal bez przerwy, całymi dniami, a właściwie - nocami” (Sobolewski, 1996: 235). 
W wierszu zwraca uwagę przemieszanie elementów kultury popularnej, jarmarcznej (karuzela) z elementami wyrafinowanej sztuki malarskiej. Odwołania ikonograficzne są przekształcone, zapośredniczone: „Leonardy min” i „obroty Rafaela” to nie same przedstawienia plastyczne, lecz ich echa, rzec można nawet pastisze. „Madonny przedmieść”, które z Madonnami z renesansowych obrazów łączy przede wszystkim specyficzna poza, w jakiej trzymają dzieci, zdają się być podobne do świętych przedstawień także fizjonomią. To podobieństwo jest jednak chwiejne, oscylujące na pograniczu imitacji i karykatury, gdyż „nie wiadomo, która śpi, a która jest natchniona”. Wreszcie podsumowaniem tej swoistej fuzji pewnej tradycji ikonograficznej i jej „opadu kulturowego” jest, rozczłonkowana przez fragmentację wersu ilustrującą wyhamowywanie karuzeli, fraza:

I peryfe
rafa
elickie
madonny
przed
mieścia

(Białoszewski, 1987: 38)

Skojarzone ze sobą w tej kodzie morfemy stanowią kombinację pól semantycznych pojęć takich jak „peryferyjny”, „rafaelicki”, i - nieco bardziej rozbitego, lecz również możliwego do odczytania - słowa "prerafaelicki”.

$\mathrm{Na}$ fuzję stylów, charakterystyczną dla kultury peryferyjnej (eksplorowaną już przez Rimbauda i podniesionej do rangi istotnego paradygmatu estetycznego przez Apollinaire’a), nakłada się inna fuzja: wizualno-akustyczna. Otóż tytułowa karuzela rusza nie w ciszy, lecz do wtóru melodii. Pojawienie się dźwięków jest motywowane realistycznie, bowiem mechanizm katarynkowy stanowił często integralną część mechanizmu karuzeli; jednak poeta ignoruje realistyczne źródło muzyki - nie wspomina o mechanizmach grających sprzężonych z motorem, skupiając się na analogii wizualnej między obrotami karuzeli a działaniem gramofonu i wprowadzając specyficzną konstrukcję quasi-cytatu:

Lata dokoła

Gramofonowa

Płyta,

Taka

płyta:

(Białoszewski, 1987: 37) 
Co oznacza zastosowany przez poetę na końcu frazy dwukropek? Czego przywołania jest znakiem - wizji czy fonii? Ciąg dalszy wprowadza konsternację o tyle, że nadal mowa jest o efektach wizualnych, a nie dźwiękowych ${ }^{8}$ :

Migają w krąg anglezy grzyw

I lambrekiny siodeł,

I gorejące wzory bryk

Kwiecisto-laurkowe.

(Białoszewski, 1987: 37)

Brak informacji na temat charakteru „cytowanej” muzyki, stowarzyszony z silnym umuzycznieniem tego fragmentu, sugeruje, że zawartość „płyty” jest reprezentowana samym brzmieniem wiersza, a więc mamy do czynienia z muzycznością I (Hejmej, 2002: 53-67). Dwie następujące po owym dwukropku strofy cechuje bowiem szczególnie rygorystyczna i kunsztowna organizacja rymów i rytmów. Po ich przebiegu następuje quasi-komentarz: „I coraz wolniej karuzela / Puszcza refren” (Białoszewski, 1987: 38), który potwierdza, że owe strofy wprowadzone dwukropkiem stanowią właściwy „cytat” muzyczny. Ale stopniowe „wyhamowywanie” melodii, odtworzone w wierszu, właściwe jest działaniu katarynki, a nie płyty gramofonowej'. Współistnieją więc w tym utworze - na poziomie jego konstrukcji - dwie mechaniki, różniące się strukturą przebiegu fonograficznego - struktura katarynki i struktura płyty. Mamy tu do czynienia z fuzją wrażeń fonograficznych, należących do różnych porządków, a zarazem z ich rozdzieleniem. W synestezyjnej poetyce Karuzeli z Madonnami struktura fonosfery ${ }^{10}$, sygnalizowana wzmianką o gramofonowej płycie, została wyodrębniona z audiosfery świata przedstawionego: „cytat” muzyczny flankowany jest klamrami części pierwszej i czwartej tekstu, swobodnie rytmizowanymi i onomatopeicznymi, ilustrującymi eksklamacje, zachęcające do skorzystania z jazdy na karuzeli, podczas gdy dwie bliźniacze pod względem kon-

8 Na wizualną dominantę wiersza zwracał uwagę już Jerzy Wiśniewski, dodając, iż wprowadzenie gramofonowej płyty jest „śmiałym posunięciem wyobraźni, mającym wiele wspólnego z właściwościami dziecięcej świadomości” (Wiśniewski, 2004: 23).

9 Takie zjawisko występowało w gramofonach na korbkę, które jednak już w czasach, kiedy powstawał wiersz, zostały wyparte przez odtwarzacze z napędem elektrycznym.

10 Słowa „fonosfera” używam na określenie zespołu dźwięków odtwarzanych z nagrania; pod pojęciem „audiosfera” rozumiem zespół dźwięków słyszanych przez podmiot - także dźwięków wyobrażonych lub halucynacji dźwiękowych, podczas gdy termin „sonosfera” rezerwuję dla zespołu dźwięków wytwarzanych w danej przestrzeni świata realnego; na temat rozmaitych definicji tych pojęć: Gołaszewska (1997: 78-81), Misiak (2009: 30-38). 
strukcyjnym środkowe strofy, uderzające swoją regularnością, naśladują brzmienie muzyki towarzyszącej obrotom mechanizmu wożącego w kółko kobiety i ich dzieci.

Efektowna fantazja wizualno-akustyczna, jaką jest wiersz, stanowi specyficzny przykład umuzycznienia wiersza. Mimo że - a może właśnie dlatego że - mamy precyzyjnie wskazane źródło dźwięku, nie otrzymujemy żadnych informacji na temat charakteru muzyki; na poziomie semantyki słownej wiersz - powtórzmy - operuje wyłącznie walorami wizualnymi. Synestezja tworzy się z połączenia warstwy przedstawień i warstwy brzmień słów. Muzyka nie jest w wierszu opisywana czy charakteryzowana, lecz jest reprezentowana fonicznie. Wiersz cytuje muzykę; odbiorca wiersza musi ją wysłuchać z brzmień jego głosek; wiersz działa więc jak gramofon, odtwarza muzykę. Jest to zgodne z zasadą wypowiedzianą przez Białoszewskiego wiele lat później, ale dającą się zastosować do wszystkich jego wierszy:

Czasem poezja przekazuje sprawy między odczuciem, myśleniem, wrażeniem, sądem, pojęciem. Dochodzi do tego zmaterializowanie tego wszystkiego w słowa (...). Warstwa dźwiękowa jest konieczna. Tak samo przy czytaniu. Prawdziwe czytanie, na głos, a nawet po cichu, musi odrabiać pełne brzmienie. Przelatywanie bez tego to jest niedobry skrót odbioru”.

(Taranienko, 1986: 402-403)

Karuzela z Madonnami właśnie „materializuje” w słowach towarzyszącą działaniu karuzeli muzykę ${ }^{11}$, tworząc strukturę, dla której pełnego zrozumienia i aktualizacji kluczowy jest koncept gramofonowej płyty. Wiersz „odtwarza” to, co zarejestrowała wrażliwość audytywna poety. Białoszewski w tym utworze niejako „puszcza płytę”, tak jak wielokrotnie puszczał nagrania swoim gościom i przyjaciołom; odbiorca

11 Nieco podobny zabieg „cytowania” został zastosowany w, również należącej do Ballad peryferyjnych, Balladzie z makaty; sytuacja jest tu jednak odmienna, bardziej tradycyjna, bowiem ową „zacytowaną” w wierszu piosenkę „śpiewa” postać z makaty. Również w Tryptyku pionowym dwukropek został wykorzystany jako figura wprowadzająca quasi-cytat, czy też właściwie (ze względu na dominantę wizualna) „ilustrację” trzech poziomów domu, porównanych do trzech skrzydeł ołtarza, z ich bohaterkami noszącymi imiona świętych. Kobiety, podobnie jak wykonywane przez nie ciężkie, codzienne prace, zostały w ten sposób poddane swoistej transfiguracji. Wymieniana jako pierwsza i pracująca na samym dole Cecylia (patronka muzyki) „gra na maglu” (Białoszewski, 1987: 52); muzyką skojarzone zostały jednak nie tyle dźwięki wydawane przez magiel, ile jego kształt i nazwy jego części, wywołujące ciąg asocjacyjny o charakterze fonetycznym: koło - manuał - emmanuel / wał - interwał - fuga" (Białoszewski, 1987: 52). Por. analizę tego tekstu dokonaną przez Jerzego Wiśniewskiego (2004: 27-30). 
wchodzi więc $\mathrm{w}$ pewnym sensie w rolę gościa poety - miłośnika muzyki, którego kolekcja płyt zdecydowanie przerastała kolekcję książek ${ }^{12 .}$

\section{4.}

W tekstach Pawlikowskiej i Białoszewskiego impuls dla poetyckiej wyobraźni stanowi nie sam tylko fenomen odtworzenia dźwięku, lecz także sposób jego wywoływania, zasada działania gramofonu, a zwłaszcza związany z nią ruch obrotowy. Inne nieco kierunki myślenia wyznacza mechanizm odtwarzacza kompaktowego, który od gramofonu różni nie tylko cyfrowa jakość, ale i to, że ruch płyty jest niewidoczny; i nawet jeśli mamy do czynienia z odtwarzaczem o przeźroczystej obudowie, ruch ten jest ruchem wewnętrznym, zamkniętym. Niektóre typy gramofonów, patefonów czy adapterów także wprawdzie umożliwiały zamknięcie pokrywy podczas działania (we wczesnych modelach był to jeden ze sposobów regulacji głośności), jednak zamknięcie i otwarcie nie było funkcyjnie związane z działaniem mechanizmu, podczas gdy w przypadku odtwarzacza kompaktowego otwarcie szuflady płytowej oznacza z reguły zatrzymanie muzyki.

Owo działanie, którego nie widać, owa muzyka nie tylko akuzmatyczna (Schaeffer: 106-112), lecz także - przynajmniej na pierwszy rzut oka - pozbawiona materialnego zakorzenienia, stały się punktem wyjścia sytuacji muzycznej otwierającej wiersz Adama Zagajewskiego:

\section{Liturgia prawosławna}

Głębokie głosy proszą natarczywie o zmiłowanie i nic nie mają na swoją obronę poza tym, że tak wspaniale śpiewają - chociaż nikogo nie ma w pokoju i tylko bardzo szybko obraca się, wiruje niewidoczna płyta.

\footnotetext{
12 „Był stałym klientem sklepów płytowych (...). Miał ogromny, idący chyba w tysiące, zbiór płyt. I one - a nie książki - stanowiły jego bibliotekę. Książek miał mało. Trzymał je w tapczanie, a na Lizbońskiej biblioteczką był piekarnik piecyka gazowego. (...) Płyty kupował raczej dla utworów niż dla wykonawców, choć o tych ostatnich miał wyrobione zdanie. Jego zbiór zawierał całą dostępną klasykę muzyczną (...)” (Sobolewski, 1996: 235).
} 
Głos jednego z solistów wywołuje z pamięci dykcję Josifa Brodskiego, recytującego swoje niezwykłe wiersze przed amerykańską publicznością, która nie wierzyła wcale w możliwość wniebowstąpienia, lecz zdawała się szczęśliwa, że ktoś inny wierzył.

Wystarczy chyba - lub tylko tak myślimy

- żeby ktoś inny wierzył za nas.

Niskie głosy wciąż śpiewają.

Zlituj się nad nimi.

Zmiłuj się i nade mną, niewidoczny Panie.

(Zagajewski, 2005: 8)

Zasadnicza dla tego utworu kwestia wiary - wiary „cudzej”, ale mającej moc ocalania, moc pośrednictwa, moc świadectwa - dobrze korespondująca z przewijającym się przez całą właściwie poezję Zagajewskiego wątkiem „cudzego piękna” - została złączona z wątkiem niewidzialnej obecności. Sytuacja fonograficzna w niezwykle subtelny sposób ukazuje ambiwalencję owej „wiary zapośredniczonej”: informacja o tym, że nikogo nie ma w pokoju, konsternująca wobec obecności implikowanej przez ludzki głos, zostaje natychmiast wyklarowana wyjaśnieniem, że są to głosy nagrane. Informacja, że obraca się niewidoczna płyta, powoduje wyjście poza perspektywę elementarnej percepcji, w stronę wiedzy o tym, co niedostrzegalne na poziomie realistycznym, ale uznane za istniejące na podstawie symptomów - znając zasadę działania odtwarzacza, wiemy, że tam obraca się płyta. Ta znajomość ukrytej mechaniki stoi w analogii do refleksji na temat działania wiary przekazywanej przez innych, wiary, o której świadczą inni - tak jak w przypadku odtwarzacza kompaktowego zakładamy, że coś istnieje i działa, bo widzimy tego następstwa. Zamykająca obraz apostrofa do „niewidzialnego Pana” w zaskakujący sposób odsyła na powrót do „niewidzialnej płyty” z pierwszej strofy. Koncept wydaje się śmiały, lecz zarazem niezwykle sugestywny: przedstawiona zasada poznania, zrozumienia, w obu przypadkach - i w sytuacji muzycznej, i w sytuacji epistemologicznej - jest ta sama: wiemy / wierzymy, że istnieje, bo słyszymy efekty, bo możemy obserwować symptomy. 
Rozmaite urządzenia do odtwarzania muzyki są przedmiotem intensywnego zainteresowania Macieja Woźniaka, którego należy zdecydowanie zaliczyć do grona "poetów muzycznych”, biorąc pod uwagę zwłaszcza tom Iluminacje, zaćmienia, szarość (Kraków, 2000), w całości inspirowany muzyką. Poświęcenie całego zbioru poetyckiego sztuce dźwięków jest pewną rzadkością, co zresztą we właściwy sobie, nieco ironiczny, ale zasadniczo afirmatywny sposób skomentował Adam Wiedemann:

Wiersze o muzyce?, wszyscy dziś piszą o muzyce, nietrudno jest usłyszeć jakąś muzykę i wstawić ją do wiersza, ale żeby zaraz całą książkę? Nawet Jarosław Iwaszkiewicz pisząc swoją „Muzykę wieczorem” dał tam zaledwie parę próbek, i wcześniej też, nigdy nie podjął takiego maksymalistycznego wyzwania, a przecież był do tego ewidentnie stworzony. I inni tak samo, musieliśmy dopiero poczekać na Macieja Woźniaka, Maciej Woźniak potraktował muzykę jako jedyną siłę sprawczą swoich wierszy, postanowił nas tą muzyką na śmierć zamęczyć i jest to z jego strony jakiś nieodpowiedzialny eksces, bo przecież nikomu nie chce się czytać pięćdziesięciu siedmiu wierszy o muzyce, acz z drugiej strony udowodnił nam, że taki czy inny z góry narzucony temat, jakkolwiek czyni książkę jednorodną i przez to rozpoznawalną, nie wymusza bynajmniej wszechstronnej jednostajności.

(Wiedemann, 2016: 277-278).

Iluminacje, zaćmienia, szarość Macieja Woźniaka to istotnie kopalnia różnego rodzaju odniesień do muzyki - rozmaitej zresztą. Można odnieść wrażenie, jakby poeta przez czas jakiś przechowywał, odkładał, gromadził muzyczne wiersze, w pewien sposób je „oszczędzając” na tom muzyczny (w którym zresztą inspiracje muzyczne bynajmniej się nie wyczerpują - pojawiają się one i w innych zbiorach). Owe poetyckie „oszczędności” - oczywiście jeśli faktycznie miały miejsce - nie były jednak składane przypadkowo, raczej noszą znamiona celowej inwestycji - tom bowiem cechuje wyrazista kompozycja, a muzyka jako zasada i temat wierszy jest wyzyskana przemyślnie, by nie rzec - strategicznie.

Tytułowe iluminacje, zaćmienia i szarość to tytuły trzech części tomu, wyznaczające dominantę nastrojową każdej z nich. Wiersze, których głównymi bohaterami są urządzenia grające, zajmują wyeksponowane miejsca w zbiorze - wiersz Promień stanowi jego otwarcie, wiersz Śmierć jest jak walkman zamyka go. Stary gramofon życia rozpoczyna trzecią część zatytułowaną Szarość; po nim zaś następują wiersze Czarna skrzynka i Kotka na goracym od muzyki wzmacniaczu. Nie chcąc jednak, by zacytować raz jeszcze Wiedemanna, „na śmierć zamęczyć” analizą wszystkich tych 
utworów, skupię się jedynie na trzech, w sposób najbardziej, jak sądzę, wyrazisty wykorzystujących specyfikę mechanizmów grających.

\section{Promień}

Wąski promień laserowego światła, błądzący przez ciemną przeszłość, zawieszona nad światem ścieżka wydeptana w błękicie przez cienie.

Wąski promień laserowego światła, cienka rysa na gładkim szkle ciszy, przezroczysty stalaktyt dźwięku rosnący przez wieki pod niebem.

Wąski promień laserowego światła, trakt dla zmęczonych pielgrzymów w szarych kapturach psalmów i trubadurów z pochodniami serc.

Wąski promień laserowego światła, ścieżka wydeptana przez cienie, dla których jedyną opatrznością jest oko kompaktowego odtwarzacza.

(Woźniak, 2000: 6)

Tytułowy promień, umożliwiający odczyt zapisu cyfrowego dźwięku, stanowi punt wyjścia dla metaforycznych analogii, służących charakterystyce nie tyle muzyki (ta bowiem pozostaje nieokreślona), co jej pochodzenia. Pasmo laserowego światła zostaje metaforycznie połączone z topiką drogi, ścieżki, traktu; jego działanie służy ukazaniu dwóch zasadniczych odniesień dla sztuki dźwięków w wierszu, jakimi są przeszłość i metafizyka. Odtwarzacz ukazany w tej perspektywie nabiera cech machiny magicznej: z jednej strony pełni funkcję swoistego wehikułu czasu, z drugiej - umożliwia kontakt z tym, co „ponad światem”, w domenie „duchów”. Wyrazisty aspekt metafizyczny tego tekstu, zaznaczony od razu w pierwszej strofie, jest w przebiegu wiersza doprecyzowywany metaforyką religijną (trakt dla zmęczonych pielgrzymów), kulminując w finalnym porównaniu lasera do oka opatrzności.

Nieco podobnie jak w wierszu Zagajewskiego metaforyzacji został poddany element o tyle specyficzny, że z zasady niewidoczny. Wiedza o nim jest wiedzą 
o ukrytym działaniu mechanizmu, jest rodzajem wtajemniczenia - co dobrze koresponduje z zasygnalizowaną w tytule części tomu ideą „iluminacji”.

Muzyka w wierszu przedstawiona jest w sposób zasadzie tradycyjny, jako zjawisko o wymiarze metafizycznym, jako substytut religii, czy wreszcie - jako przekaźnik pamięci kulturowej (stalaktyt „rosnący przez wieki”). Koncept zbudowany na wykorzystaniu właściwości technicznych odtwarzacza cyfrowego odświeża dobrze zadomowione w kulturze ujęcia muzyki, nie dokonując ich rewizji czy aktualizacji w świetle nowoczesności, której ów odtwarzacz jest reprezentantem. Format cyfrowy nie zmienia sposobu myślenia o muzyce, ale mechanizm jego działania jest źródłem nowych metafor - odświeża topikę poetyckiej „muzykologii”.

Woźniaka inspirują jednak także dawniejsze narzędzia fonograficzne:

\section{Stary gramofon życia}

Stary gramofon życia wirujący cierpliwie ciężki talerz planety, nad którym sinym cieniem pochyla się ramię nieba.

Stary gramofon życia, zakurzony, zmęczony, archaiczny mechanizm, dźwigający z wysiłkiem zdarte płyty oddechów.

Stary gramofon życia, wyśmiany przez technikę, zawstydzony, niemodny, niepraktyczny bibelot ze stępioną igłą sensu.

(Woźniak, 2000: 55)

Anachroniczne urządzenie grające staje się podstawą metafory najpierw przez swój kształt i zasadę działania: obroty mechanizmu grającego i praca ramienia z igłą odtwarzającą, skojarzone z obrotami ciał niebieskich, stają się obrazem funkcjonowania kosmosu. Słowo „stary” nie jest w tej pierwszej strofie nacechowane negatywnie, raczej konotuje z dawnością wszechświata, zaś pojęcie „życia” ma przy tym wymiar bardzo szeroki. Od tej kosmicznej perspektywy przechodzimy jednak 
w strofie drugiej do innego porządku metaforycznego, nacechowanego antropomorfizmem - życie przedstawiane jest tu już w ujęciu biologicznym, a tym samym jego starość wiąże się z wyczerpaniem, zmęczeniem, zużyciem. Trzecia strofa na początku zdaje się wyprowadzać gramofon ze sfery metaforyzacji, przedstawiając go w perspektywie postępu technicznego; jednak w kontekście dwóch wcześniejszych zwrotek jasne jest, że konfrontacja wartości przebiega tu nie na linii stare-nowe urządzenia, ale na linii natura-technika, tradycja-postęp, jako że ów „niepraktyczny bibelot" oznacza życie, w jego wymiarze kosmicznym i jednostkowym. Następuje tu konfrontacja tego co dawne, co naturalne, lecz stare z tym, co nowe, i czego sens, być może, nie został (jeszcze) stępiony. Szczególnie interesujące w tym koncepcie jest usytuowanie gramofonu - niewątpliwie narzędzia postępu technicznego - po stronie natury, a więc wyodrębnienie go ze sfery myśli technicznej i zawłaszczenie przez sferę „życia”, do czego zdaje się skłaniać i uprawniać jego dawność. Takie potraktowanie starej maszyny przywodzi na myśl refleksję nad specyfiką ruiny ${ }^{13}$ : budynek, który stał się ruiną, integruje się z naturą, mimo że powstawał jako dzieło cywilizacji. Podobnie dawność gramofonu decyduje o jego „naturalizacji”; granica między techniką a naturą okazuje się płynna i zmienna. Nie mamy tu właściwie do czynienia z refleksją nad muzyką - kontemplacja urządzenia grającego prowadzi poetę w zupełnie innym kierunku, choć metafora „zdartych płyt oddechów” może być uznana za następstwo konfrontacji walorów analogowego i cyfrowego formatu zapisu dźwięku.

\section{Śmierć jest jak walkman}

Śmierć jest jak walkman.

Przenośna i z własnym zasilaniem.

$\mathrm{Z}$ zewnątrz nic nie słychać.

Ale wystarczy nałożyć ją na uszy,

aby sprawdzić czy Mozart dokończył Requiem.

Śmierć jest jak walkman.

Podręczna. Prosta w użyciu.

Łatwa do ukrycia pod ubraniem.

13 Przeglądu rozmaitych konotacji symbolicznych ruin dokonuje Grażyna Królikiewicz, analizując przede wszystkim materiał dziewiętnastowieczny, ale zarazem ukazując jednak w wielu aspektach uniwersalne składniki topiki ruin (Królikiewicz, 1993). 
W każdej chwili można usłyszeć, jak brzmi Dziesiąta Symfonia Beethovena.

Śmierć jest jak walkman.

W epoce kultury masowej

jej popularność stale rośnie.

Każdy ma prawo się dowiedzieć,

o czym śpiewa ostatnio Billie Holiday.

Śmierć jest jak walkman.

Możesz jej nawet nie czuć w kieszeni.

Cienki czarny przewód to wszystko, co cię z nią łączy. Do końca

nie wiesz, czy kaseta nie jest pusta.

(Woźniak, 2000: 73)

Barokowy koncept tego wiersza pod wieloma względami przywodzi na myśl cykl Pawlikowskiej-Jasnorzewskiej; z Ptytami Carusa wiąże go nie tylko topika funeralna i konsekwentna, paralelna struktura metaforyzacji, lecz także to, że muzyka sytuowana jest w nim po „tamtej stronie”. W utworze tym jednak metafizyczna granica została przesunięta - śmierć jest domeną nie tej muzyki, która trwa dłużej niż życie jej wykonawcy, lecz tej, która nie zaistniała i być może nigdy nie zaistnieje. Możliwość izolacji, uniezależnienia od otoczenia, wejścia w inny świat - świat muzyczny, jaki daje walkman - została, prawem analogii, przekształcona w wizję za-światów. Katalog niedokończonych, planowanych utworów, stanowiących potencjalną kontynuację „ziemskiej” twórczości muzycznej, jest synekdochą eschatologicznych nadziei, których chwiejność dobitnie ilustruje koncept potencjalnie „pustej kasety” śmierci. Ów brakujący „trzeci wymiar”, o którym pisał Adorno - wymiar obecności - został przez Woźniaka utożsamiony z wymiarem ostatecznym - podniesiony do rangi pytania zasadniczego o Obecność.

\section{6.}

Przywołane wiersze mają charakter niejednolity, pochodzą z różnych okresów wieku $\mathrm{XX}$, od bardzo różnych poetów, charakteryzują się także rozmaitym stopniem złożoności artystycznej i myślowej. Oczywiście zostały dobrane arbitralnie, ale zarazem tak, aby ukazać możliwe szerokie spektrum sposobów poetyckiego wykorzystania nośników i urządzeń fonograficznych. Każdy z tych tekstów eksploatuje w nieco inny 
sposób działanie i wygląd mechanizmu odtwarzającego muzykę; lecz w pewnym sensie wszystkie razem są podobne i reprezentatywne - gdyż w ich konfrontacji z ujęciem Adorna szczególnie wyraziście rysuje się odmienność celów i przesłanek, jakimi kieruje się wykorzystujący metaforę filozof-muzykolog oraz poeta. Pierwszy, choćby tak subiektywnie uwarunkowany i stronniczy jak Adorno, zmierza jednak zasadniczo do uchwycenia istoty opisywanej rzeczy, w centrum zainteresowania stawiając samą muzykę i towarzyszące jej artefakty; poeta natomiast z reguły zawłaszcza je i funkcjonalizuje, przekraczając horyzont muzykologiczny, traktując namysł nad nimi jako drogę prowadzącą do uchwycenia czegoś więcej niż sama muzyka i jej kulturowe otoczenie ${ }^{14}$. Tak dzieje się właściwie zawsze, niezależnie od tego, jakiego nośnika fonograficznego dotyczy poetycka refleksja i w jakim kierunku przebiega.

Owa „dwuwymiarowość” fonograficznego przekazu muzyki, o której pisał z niechęcią Adorno, owo odcięcie "trzeciego wymiaru” dla poetów okazało się impulsem szczególnie inspirującym. Pusta - opróżniona przez fonografię - sfera w doświadczeniu muzycznym została przez nich po swojemu zagospodarowana. Stworzony przez nich alternatywny „trzeci wymiar” obcowania z muzyką niewiele ma wspólnego z tym pierwotnym, ale nie jest przez to mniej wartościowy, choć jego wartość na czym innym polega: otwiera nowe możliwości poetyckiej „muzykologii”, wyrażającej się nie w próbach werbalnej translacji czy transpozycji doświadczenia muzycznego, nie w wejściu w „konkurencję” wyrazową z fenomenem muzycznym, lecz w namyśle nad jego ontologią jako drogą poznania o charakterze ogólniejszym. Nośniki dźwięku, które w pewien sposób materializują muzykę, wyprowadzają ją z ograniczonych rewirów, zarezerwowanych dla nacechowanego efemerycznością obcowania z nią „na żywo”, umożliwiając jej włączenie w praktycznie wszystkie sfery ludzkiego doświadczenia. Jeśli, zgodnie z tradycją (między innymi heglowską), uznamy muzykę za najbardziej metafizyczną ze sztuk, jasna stanie się doniosłość fonografii, która umożliwia ścisłą integrację tego elementu metafizycznego z codziennym bytowaniem. Obrazowanie we wszystkich analizowanych wierszach wiąże się z różnego rodzaju uobecnieniem tego, co już nieistniejące lub inaczej niedostępne, a czego zapis fonograficzny jest śladem, świadectwem lub analogonem; płyta jest znakiem obecności jakości nieuchwytnych zmysłami. Każdy z przywoływanych wierszy jest kontrargumentem przeciw tezom Adorna - jest apologia „, formy płyty” i wszelkich form, jakie przybiera fonografia; ukazuje, że muzyka w zapisie fono-

14 Różnica ta dobrze ilustruje niewystarczalność retorycznego definiowania poezji, w konfrontacji np. z ujęciem P. de Mana (1979: 3-19), ukazując ważność kategorii - nomen omen - uobecnienia oraz odmienną celowość zastosowania metafory (Bonnefoy, 1997: 7-9). 
graficznym, tracąc jeden z wymiarów muzycznego życia, jednocześnie zyskuje inny, zyskuje „życie wtóre”, dobrze współgrając z poezją, a zarazem stając się nośnikiem wartości przekraczających ją samą. To, czy Adorno, w swojej optyce wierności muzyce, uznałby taką apologię za wskazaną - to już osobna kwestia.

\section{Bibliografia}

Adorno, Theodor Wiesengrund. Musikalische Schriften, VI. Hrsg. Rolf Tiedemann. Darmstadt: Wissenschaftliche Buchgesellschaft, 1998.

Białoszewski, Miron. Utwory zebrane. T. I. Warszawa: Państwowy Instytut Wydawniczy, 1987.

Bonnefoy, Yves. „Avant-propos”. Poésie et rhétorique: la concsience de soi de la poésie: colloque de la Fondation Hugot du College de France. Ed. Odile Bombarde, Paris: Lachenal \& Ritter, 1997.

De Man, Paul. Allegories of Reading. New Haven-London: Yale University Press, 1979.

Encyclopedia of Recorded Sound. Ed. Frank Hoffman, New York-London: Routlege, 2005

Gelatt, Roland. The Fabulous Phonograph 1877-1977. London: Cassell, 1977.

Gołaszewska, Maria. Estetyka pięciu zmystów. Warszawa-Kraków: Wydawnictwo Naukowe PWN, 1997.

Heidegger, Martin. Technika i zwrot. Tłum. Janusz Mizera. Kraków: Baran i Suszczyński, 2002.

Hejmej, Andrzej. Muzyczność dzieła literackiego. Wrocław: Wydawnictwo Uniwersytetu Wrocławskiego, 2002.

Janczewska-Sołomko, Katarzyna. Zachować dźwięk. Warszawa: Biblioteka Narodowa, 2000.

Kominek, Mieczysław. Zaczęto się od fonografu, Kraków: PWM, 1986.

Kwiatkowski, Jerzy. „Wstęp”. Pawlikowska-Jasnorzewska, Maria. Wybór poezji. Wrocław-Warszawa-Kraków: Ossolineum, 1969.

Lesueur, Daniel. L'histoire du disque et de l'enregistrement sonore. Chatou-New York: Carnot, 2004.

Marty, Daniel. Histoire illustrée du Phonographe. Lausanne-Paris: Edita-Lazarus, 1979.

Misiak, Tomasz. Estetyczne konteksty audiosfery. Poznań: Wydawnictwo WSNHiD, 2009.

Pawlikowska-Jasnorzewska, Maria. Wybór poezji. Oprac. Jerzy Kwiatkowski. WrocławWarszawa-Kraków: Ossolineum, 1969. 
Schaeffer, Pierre. „Akuzmatyka”. Przeł. Julian Kutyła. Kultura dźwięku. Teksty o muzyce nowoczesnej. Wybór i red. Christoph Cox, Daniel Warner. Gdańsk: słowo/obraz terytoria 2010.

Sobolewski, Tadeusz. „Post scriptum: Muzyka u Mirona”. Miron. Wspomnienia o poecie. Oprac. Hanna Kirchner, Warszawa: Tenten, 1996.

Szargot, Maciej. „Głos i śmierć. O cyklu Ptyty Carusa Marii Pawlikowskiej-Jasnorzewskiej”. Semiotyka cyklu. Cykl w muzyce, plastyce i literaturze. Red. Mieczysława Demska-Trębacz, Krystyna Jankowska, Radosław Sioma. Białystok: Wydawnictwo Uniwersytetu w Białymstoku, 2005.

Taranienko, Zbigniew. Rozmowy z pisarzami. Warszawa: Wiedza Powszechna, 1986.

Wiedemann, Adam. Postuszność. Przygody muzyczne. Wrocław: Wydawnictwo Warstwy, 2016.

Wiśniewski, Jerzy. Miron Biatoszewski i muzyka. Łódź: Wydawnictwo Uniwersytetu Łódzkiego, 2004.

Woźniak, Maciej, Iluminacje, zaćmienia, szarość. Kraków: Śródmiejski Ośrodek Kultury, 2000.

Zagajewski, Adam. Anteny. Kraków: Wydawnictwo a5, 2005.

\section{Musical Machines, Poetical Machines: Phonographic Devices in Polish Poetry in $20^{\text {th }}$ Century}

\section{Summary}

For majority of poets in the 20th century, recording was a natural way to perceive music and the phonographic devices created frames and context for many poetic creations. As the evolution of recording technology developed very quickly, the phonographic conditions of poetry changed with it. The role of musical machines in poems is usually minor: they are named or implied as a source of music in various spaces and conditions. Nevertheless, sometimes they became very important: their characteristic, form, way of working become the subject of observation, reflection, point of departure for metaphors as well as symbolic senses. The paper shows and describes a few examples of Polish poetry metamorphosing the phonographic devices (poems of Maria Pawlikowska-Jasnorzewska, Miron Białoszewski, Adam Zagajewski, Maciej Woźniak).

Keywords: comparative literature, Polish poetry, phonographic devices, music and literature

Słowa kluczowe: komparatystyka literacka, poezja polska, urządzenia fonograficzne, muzyka i literatura 